\title{
Adverse outcome of methotrexate and mini pulse betamethasone in the treatment of lichen planus
}

\author{
Hazra SC ${ }^{1}$, Choudhury $\mathrm{AM}^{2}$, Asaduzzaman $\mathrm{ATM}^{2}$, Paul $\mathrm{HK}^{2}$ \\ ${ }^{1}$ Infectious Diseases Hospital, Dhaka, ${ }^{2}$ Department of Dermatology \& Venereology, Bangabandhu \\ Sheikh Mujib Medical University, Dhaka. Email: samohazra@yahoo.com
}

\begin{abstract}
Absrtact
The objectives of this study were to compare the adverse outcome of methotrexate and mini pulse betamethasone therapy in the treatment of lichen planus. It was a clinical trial conducted in the department of Dermatology and Venereology, Bangabandhu Sheikh Mujib Medical University, Dhaka, from January 2009 to December 2010. Forty four patients of lichen planus were included in the study. Patients in Group-A, $(n=23)$ were treated with methotrexate $(10 \mathrm{mg})$ single morning dose and group-B $(n=21)$ were treated with mini pulse betamethasone $(5 \mathrm{mg})$ single morning dose on 2 consecutive days during the period of 12 weeks. Adverse outcomes were measured by clinical examination and laboratory investigations during follow up visits. Anemia 3(14.2\%) and edema 12(57.1\%) developed in group-B but none in group-A. In group-B, dyspepsia $15(71.4 \%)$, acne $10(47.6 \%)$, mooning face $8(38.1 \%)$, striae $8(38.1 \%)$ and hypertrichosis $4(19.0 \%)$ developed but none in group-A. Intermittent diarrhoea, headache, nausea and fatigue complained in both groups of patients but the percentage of complaints was higher amog group-B compared to group-A. Menstrual abnormality developed in group-B 5(71.4\%) but none in group-A. Laboratory investigations showed abnormality in platelet count and SGPT in group-A but none in group-B. The adverse effects of methotrexate on haematological parameter and liver functions were mild and could be prevented by reducing the dose but the adverse effects of betamethasone were unavoidable. The overall adverse effects were less in group-A than group-B. Therefore, methotrexate can be used as an alternative safer option for the treatment of lichen planus.
\end{abstract}

\section{Introduction}

Lichen planus is an inflammatory mucocutaneous disease characterized by shiny, violaceous, polygonal, flat topped, firm papules and plaques with Wickham's striae on the surfaces of lesions ${ }^{1}$. It is highly pruritic ${ }^{2}$. T cells become activated via antigen-presenting cells such as Langerhans cells in conjunction with epidermal keratinocytes and costimulatory molecules. These activated $\mathrm{T}$ lymphocytes play a pivotal role in regulating epidermal cell recognition, the lichenoid response and basal cell damage. Lichen planus is an unpredictable disease that typically persists for 1 to 2 years, but may follow a chronic, relapsing course over many years ${ }^{3}$. Lichen planus may cause atrophic cicatricial alopecia and nail dystrophy with the involvement of scalp and nail respectively ${ }^{4}$. Skin lesions of lichen planus may be disfiguring. Involvement of the oral and genital mucosa in severe cases may be debilitating. Oral lichen planus may predispose to the development of squamous cell carcinoma within the lesions ${ }^{1}$. Methotrexate is the most commonly dermatologist-prescribed oral immunosuppressive agents. ${ }^{\mathbf{5}}$. Methotrexate is mainly related to its effect on epidermal cell proliferation. It has a more significant effect on lymphoid cells. Methotrexate has antiinflammatory effects and its anti-inflammatory effects exerts via inhibition of lymphocyte proliferation. So methotrexate can be a highly effective treatment alternative to systemic corticosteroid and other systemic drugs in the treatment of lichen planus ${ }^{21}$. Topical potent to ultra potent corticosteroids are widely used as first-line treatment, but response often incomplete ${ }^{14}$. Topical treatment is impractical and patient compliance is usually poor for patients with generalized lichen planus $^{21}$. Oral corticosteroids result in prompt improvement but relapse is common as the dose is reduced $^{25}$ and it is related with many side- effects including hyperglycemia, proximal myopathy, osteoporosis, acne, mooning face, central obesity, weight gain, menstrual abnormality, hirsutism, peptic ulcer and growth retardation in children. These side effects of systemic steroids are unavoidable ${ }^{26}$. But methotrexate is well tolerated and convenient dose schedule with mild to moderate gastrointestinal, hepatic, renal and hematological side effects that can be deceted before they become serious and take measures to 
prevent it. So, methotrexate can be a highly effective and tolerable treatment alternative to systemic corticosteroid in the treatment of lichen planus ${ }^{6}$.

Treatment of lichen planus is difficult and a lack of randomized controlled clinical trial makes evaluation of therapies challenging ${ }^{6}$. For safer treatment option a prospective, randomized controlled clinical trial of oral methotrexate is necessary in our country, to find out an alternative safer drug for the treatment of lichen planus.

\section{Materials and Methods}

A prospective clinical trial was conducted in the department of Dermatology and Venereology, Bangabandhu Sheikh Mujib Medical University (BSMMU), Dhaka, Bangladesh. The patients of lichen planus attending at the department of Dermatology and Venereology, during the period of January 2009 to December 2010 were enrolled in this study. Total 44 patients were enrolled following inclusion and exclusion criteria. Of them 23 patients in group-A and 21 patients in group-B were selected alternately. A data collection sheet was used for research instrument.

Selection criteria: Both male and female patients having 18 years or more, clinically and histopathologically diagnosed lichen planus and baseline investigatios such as CBC, liver and renal functions tests were normal and willng to participate in this study were selected as our study patients. After exclusion of co-morbidity (acute infection, diabetes mellitus, uncontrolled hypertension, neoplasia, hepatic, renal and haematological diseases), pregnancy and lactation, the selected patients were finally included as our study participants.

Study procedure: Patients reported as lichen planus clinically and histopathologically at BSMMU and fulfil inclusion and exclusion criteria were selected for study. History, clinical examination and baseline haematological and biochemical test of blood (CBC, liver and renal function tests, random plasma glucose) were done before intervention. Group-A patients were given oral methotrexate 10 mg (Tab. Methotrax $10 \mathrm{mg}$ ) single morning dose after breakfast once in a week and oral folic acid 5 $\mathrm{mg}$ (Tab. Folison $5 \mathrm{mg}$ ) single morning dose after breakfast on the next day of methotrexate dose for 12 weeks. Group-B patients were given oral betamethasone $5 \mathrm{mg}$ (Tab. Betnelan $0.5 \mathrm{mg}, 10$ tablets at a time) in a single morning dose after breakfast on 2 consecutive days of every week for 12 weeks.
Follow up: Patients were followed up for adverse effects of therapy at $1^{\text {st }}, 2^{\text {nd }}, 6^{\text {th }}$ and $12^{\text {th }}$ week. Adverse effects of drugs were recorded as patient complaints and clinical evaluation. Patients were monitored by physical and dermatological examinations, and laboratory investigations such as CBC and SGPT weekly for first 2 weeks, then after 6 weeks and 12 weeks. Random plasma glucose (RBS) was done at baseline and after 12 weeks completion of treatment. The treatment with methotrexate was stopped if total count of WBC $<4000 / \mathrm{cu}$ mm or platelet count $<100,000 / \mathrm{cu} \mathrm{mm}$ of blood or SGPT exceeded 3 times of the upper limit of normal value. When WBC, platelet count and SGPT were return to normal, methotrexate was started at a lower dose. Photographs of lesions at baseline and then after 6 weeks and 12 weeks were taken for subsequent assessment and compare.

Data processing and analysis: After collection, data was checked for inadequacy, irrelevancy and inconsistency. All data was analyzed with appropriate statistical tools and SPSS 15 program and presented as text, tables and figure.

\section{Results}

Total 44 patients with complete data were included in the study. The mean age of group-A $(n=23)$ was $34.9( \pm 13.4)$ years ranging from 18 to 60 years, whereas the mean age of group-B $(n=21)$ was $32.9( \pm 11.4)$ years ranging from 18 to 61 years, but the mean difference was not statistically significant ( $>0.05)$, though the mean age of group-A was higher than group-B. No statistically significant sex difference was found between group-A and group$B(p>0.05)$, though the proportion of male patients were higher in group-A $9(39.1 \%)$ compared to group-B 7(33.3\%).

All the patients had skin lesion, but 19(43.2\%) had lesion in mucous membrane and $10(22.7 \%)$ had nail and $3(6.8 \%)$ had lesion in hair follicle. The mean duration of disease was $18.7( \pm 4.0)$ months for the group-A and $17.5( \pm 5.6)$ months for group-B. But the mean difference was not statistically significant $(\mathrm{p}>0.05)$ (Table I).

Table II revealed that none of group-A had developed anemia and edema in subsequent follow up. However, $3(14.2 \%)$ patients developed anemia and $12(57.1 \%)$ patients developed edema in group-B during $12^{\text {th }}$ week follow up $(\mathrm{p}<0.05)$. Analysis revealed that the mean change of body weight was noticed from baseline to $12^{\text {th }}$ week follow up. Body weight increased in group-A from $55.9( \pm 2.4)$ to $56.5( \pm 2.4)$ $\mathrm{Kg}$ and in group-B from $58.7( \pm 2.6)$ to $61.5( \pm 2.5) \mathrm{Kg}$. Mean difference of body weight was found between group-A and group- $\mathrm{B}(\mathrm{p}<0.05)$ indicating mean body weight increased in group-B compared to group-A. 
Adverse clinical symptoms like diarrhea, nausea, headache, alopecia and fatigue developed in both groups of patients during follow up period. The percentage of complaints were found to be higher among group-B compared to group-A, but the difference was not statistically significant $(\mathrm{p}>0.05)$ between two groups of patients. Dyspepsia developed in group-A 11(47.8\%), but in group-B $15(71.4 \%)$. Statistically significant difference was found between two groups of patients $(\mathrm{p}<0.05)$.

Table II also revealed that among group-A, none developed acne, mooning face and striae from baseline to follow up period. But among group-B, acne $10(47.6 \%)$, mooning face $8(38.1 \%)$ and striae $8(38.1 \%)$ developed during the follow up period. Statistically significant difference was found between two groups of patients $(\mathrm{p}<0.05)$.

Among group-A, none developed purpura and hypertrichosis from baseline to follow up period but among group-B purpura 2(9.5\%) and hypertrichosis $4(19.0 \%)$ developed during follow up period. On the contrary, mouth ulcer developed in both groups of patients during follow up. However, no statistically significant difference was found between two groups of patients $(\mathrm{p}>0.05)$ (Table II).

Among the female patients, initially none complained of menstrual abnormality among both groups of patients but during follow up period, menstrual abnormality developed in group-B $5(71.4 \%)$ and none developed menstrual abnormality among group-A(Table II).

Haematological parameters of WBC counting and ESR measurement during follow up period showed that no statically significant mean difference was observed between group-A and group-B ( $>0.05)$ (Table III). A decreasing trend of blood hemoglobin level was observed, but no statistically significant mean difference was found between two levels such as baseline to $1^{\text {st }}$ week of observation, or $1^{\text {st }}$ week to $2^{\text {nd }}$ week observation and so on $(p>0.05)$. Similarly no statistically significant mean difference was found between group-A and group-B in each level of observation such as at baseline, $1^{\text {st }}$ week, $2^{\text {nd }}$ week $\&$ so on ( $p>0.05)$ (Fig.1). Among group-A the platelet count decreased from baseline to $1^{\text {st }}$ week follow up and then gradually increased up to $6^{\text {th }}$ week, followed by decreased the count. On the contrary, a decreasing trend of platelet count was observed up to $2^{\text {nd }}$ week and then increased at $6^{\text {th }}$ week, but subsequently it decreased. Analysis indicated that no statistically significant mean difference of decreased number of platelet count in different stages within group-A and group-B ( $p>0.05)$ were observed (Fig. 2).

Biochemical parameters showed that an increasing trend of SGPT was observed among group-A and
group-B up to $6^{\text {th }}$ week of observation and then decreased. However, no statistically significant mean difference was found within the group from baseline to $1^{\text {st }}$ follow up, $1^{\text {st }}$ follow up to $2^{\text {nd }}$ follow up and so on. Similarly, no statistically significant mean difference was found between group-A and group-B in different follow up ( $p>0.05$ ) (Table III).

No statistically significant mean difference of random plasma glucose was found within and between group$A$ and group-B in different level of observation ( $>0.05)$ (Table III).

Table I: Demographic characteristics and characteristics of lesions of respondant.

\begin{tabular}{lcccc}
\hline Characteristics & $\begin{array}{c}\text { Group-A } \\
(\mathrm{n}=23)\end{array}$ & $\begin{array}{c}\text { Group-B } \\
(\mathrm{n}=21)\end{array}$ & $\begin{array}{c}\text { Total } \\
(\mathrm{n}=44)\end{array}$ & P value \\
\hline Age in years & $\mathrm{n}(\%)$ & $\mathrm{n}(\%)$ & $\mathrm{n}(\%)$ & \\
$<25$ & $6(26.1 \%)$ & $4(19.0 \%)$ & $10(22.7 \%)$ & \\
$25-34$ & $6(26.1 \%)$ & $9(42.9 \%)$ & $15(34.1 \%)$ & \\
$35-44$ & $5(21.7 \%)$ & $5(23.8 \%)$ & $10(22.7 \%)$ & \\
$45-54$ & $4(17.4 \%)$ & $1(4.8 \%)$ & $5(11.4 \%)$ & \\
$\geq 55$ & $2(8.7 \%)$ & $2(9.5 \%)$ & $4(9.1 \%)$ & \\
Mean $( \pm \mathrm{SD})$ & $34.9( \pm 13.4)$ & $32.9( \pm 11.4)$ & $33.9( \pm 12.4)$ & 0.596 \\
Range & $18-60$ & $18-61$ & $18-61$ & \\
Sex & & & & \\
Female & $14(60.9 \%)$ & $14(66.7 \%)$ & $28(63.6 \%)$ & \\
Male & $9(39.1 \%)$ & $7(33.3 \%)$ & $16(36.4 \%)$ & 0.960
\end{tabular}

\begin{tabular}{|c|c|c|c|c|}
\hline \\
\hline \multicolumn{5}{|c|}{$\begin{array}{l}\text { Characteristics of lession of LP } \\
\text { Site of lesion } \quad \mathrm{n} \%\end{array}$} \\
\hline Skin & $23(100 \%)$ & $21(100 \%)$ & $44(100 \%)$ & \\
\hline $\begin{array}{l}\text { Mucous } \\
\text { membrane }\end{array}$ & $8(34.8 \%)$ & $11(52.4 \%)$ & $19(43.2 \%)$ & \\
\hline Nail & $4(17.4 \%)$ & $6(28.6 \%)$ & $10(22.7 \%)$ & \\
\hline Hair follicle & $3(13.0 \%)$ & $0(.0 \%)$ & $3(6.8 \%)$ & \\
\hline Mean duration & & & & \\
\hline of the disease & $18.7(+4.0)$ & $17.5(+5.6)$ & $17.9(+3.4)$ & $p>0.05$ \\
\hline Range & $1-60$ & $2-120$ & $1-120$ & \\
\hline
\end{tabular}

Table II: Comparative study of the adverse effects (symptoms \& signs) of the patients during 12 weeks follows up period.

\begin{tabular}{|c|c|c|c|}
\hline \multirow[t]{2}{*}{ Characteristics } & $\begin{array}{c}\text { Group-A } \\
(n=23)\end{array}$ & $\begin{array}{c}\text { Group-B } \\
(\mathrm{n}=21)\end{array}$ & \multirow[t]{2}{*}{$\mathrm{p}$ value } \\
\hline & $\mathrm{n} \%$ & $\mathrm{n} \%$ & \\
\hline Anemia & 0 & $3(14.2 \%)$ & $\mathrm{p}<0.05$ \\
\hline Edema & 0 & $12(57.1 \%)$ & $\mathrm{p}<0.05$ \\
\hline \multicolumn{4}{|l|}{ Weight in $\mathrm{kg}$} \\
\hline Baseline & $55.9(+2.4)$ & $58.7(+2.6)$ & $\mathrm{p}<0.05$ \\
\hline $12^{\text {th }}$ week & $56.5(+2.4)$ & $61.5(+2.6)$ & $\mathrm{p}<0.05$ \\
\hline Diarrhoea & $3(13.04)$ & $2(9.52 \%)$ & $p>0.05$ \\
\hline Nausea & $7(30.4 \%)$ & $7(33.3 \%)$ & $\mathrm{p}>0.05$ \\
\hline Dyspepsia & $11(47.8 \%)$ & $15(71.4 \%)$ & $\mathrm{p}<0.05$ \\
\hline Headache & $6(26.1 \%)$ & $7(33.3 \%)$ & $\mathrm{p}>0.05$ \\
\hline Alopecia & $4(17.4 \%)$ & $1(4.8 \%)$ & $\mathrm{p}>0.05$ \\
\hline Fatigue & $8(34.8 \%)$ & $11(52.4 \%)$ & $\mathrm{p}>0.05$ \\
\hline Acne & 0.0 & $10(47.6 \%)$ & $\mathrm{p}<0.05$ \\
\hline Mooning face & 0.0 & $8(38.1 \%)$ & $\mathrm{p}<0.05$ \\
\hline Striae & 0.0 & $8(38.1 \%)$ & $\mathrm{p}<0.05$ \\
\hline Purpura & 0.0 & $2(9.5 \%)$ & $\mathrm{p}>0.05$ \\
\hline Hypertrichosis & 0.0 & $4(19.0 \%)$ & $\mathrm{p}>0.05$ \\
\hline Mouth ulcer & $3(13.0 \%)$ & $2(9.5 \%)$ & $\mathrm{p}>0.05$ \\
\hline $\begin{array}{l}\text { Menstrual } \\
\text { abnormality }\end{array}$ & 0.0 & $5(71.4 \%)$ & $\mathrm{p}<0.05$ \\
\hline
\end{tabular}




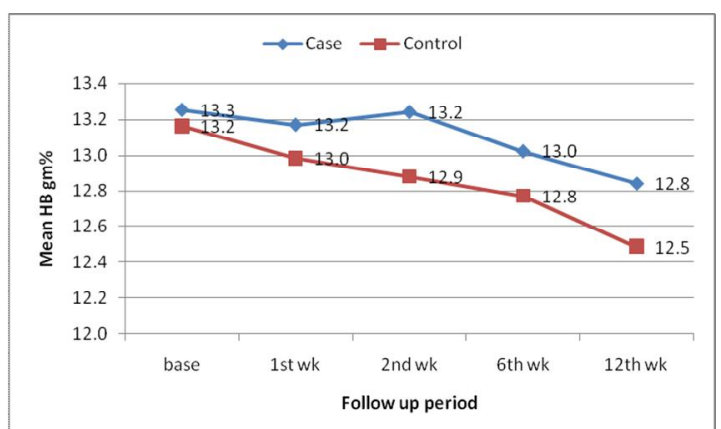

Fig. 1: Mean changes of hemoglobin level from baseline to $12^{\text {th }}$ week follow up

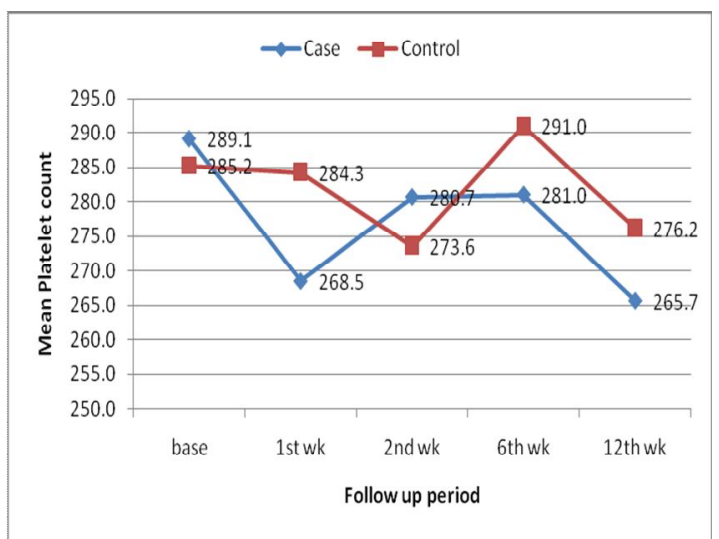

Fig. 2: Mean changes of Platelet count from baseline to $12^{\text {th }}$ week follow up.

Table II: Comparative study of the patients by follow up haematoogical \& biochemical parameters from baseline to $12^{\text {th }}$ week.

\begin{tabular}{|c|c|c|c|}
\hline Characteristics & $\begin{array}{c}\text { Group- }(\mathrm{n}=23) \\
\text { Mean }( \pm \mathrm{SD})\end{array}$ & $\begin{array}{c}\text { Group- }(\mathrm{n}=21) \\
\text { Mean }( \pm \mathrm{SD})\end{array}$ & $\mathrm{p}$ value \\
\hline \multicolumn{4}{|c|}{ TC of WBC $\left(\times 10^{9}\right)$} \\
\hline Baseline & $8.8(+0.5)$ & $8.6(+0.4)$ & $\mathrm{p}>0.05$ \\
\hline $1^{\text {st }}$ week & $9.2(+0.6)$ & $10.2(+0.6)$ & $\mathrm{p}>0.05$ \\
\hline $2^{\text {nd }}$ week & $9.3(+0.4)$ & $9.6(+0.5)$ & $\mathrm{p}>0.05$ \\
\hline $6^{\text {th }}$ week & $8.9(+0.5)$ & $9.2(+0.5)$ & $\mathrm{p}>0.05$ \\
\hline $12^{\text {th }}$ week & $8.4(+0.4)$ & $9.6(+0.4)$ & $\mathrm{p}>0.05$ \\
\hline \multicolumn{4}{|l|}{ ESR(in $1^{\text {st }}$ hour) } \\
\hline Baseline & $14.6(+1.7)$ & $18.3(+4.0)$ & $\mathrm{p}>0.05$ \\
\hline !st week & $15.2(+2.4)$ & $16.2(+3.3)$ & $\mathrm{p}>0.05$ \\
\hline $2^{\text {nd }}$ week & $17.0(+1.9)$ & $16.4(+2.6)$ & $\mathrm{p}>0.05$ \\
\hline $6^{\text {th }}$ week & $17.4(+2.5)$ & $17.0(+2.8)$ & $\mathrm{p}>0.05$ \\
\hline $12^{\text {th }}$ week & $15.7(+1.4)$ & $17.2(+1.7)$ & $\mathrm{p}>0.05$ \\
\hline \multicolumn{4}{|l|}{ SGPT U/L } \\
\hline Base & $24.2( \pm 2.7)$ & $31.4( \pm 4.1)$ & $\mathrm{p}>0.05$ \\
\hline $1 \mathrm{st} w \mathrm{w}$ & $29.7( \pm 2.6)$ & $28.7( \pm 3.1)$ & $\mathrm{p}>0.05$ \\
\hline 2nd wk & $29.3( \pm 3.9)$ & $37.1( \pm 8.2)$ & $\mathrm{p}>0.05$ \\
\hline 6th wk & $41.2( \pm 10.9)$ & $43.4( \pm 12.4)$ & $\mathrm{p}>0.05$ \\
\hline 12 th wk & $28.0( \pm 2.8)$ & $34.2( \pm 4.2)$ & $\mathrm{p}>0.05$ \\
\hline \multicolumn{4}{|c|}{ Random plasma glucose $\mathrm{mmol} / \mathrm{L}$} \\
\hline Base & $5.4( \pm 0.2)$ & $5.3( \pm 0.2)$ & $\mathrm{p}>0.05$ \\
\hline 12 th wk & $5.3( \pm 0.2)$ & $5.6( \pm 0.3)$ & $\mathrm{p}>0.05$ \\
\hline
\end{tabular}

\section{Discussion}

This study was done to assess the safety of oral methotrexate therapy in the treatment of lichen planus. In the present study, the mean age of all the study subjects was $33.9( \pm 12.4)$ years with a range of 18 to 61 years. It also showed that $30(56.8 \%)$ of the study subjects were within $25-44$ years age group. Kachhawa et al. and Khondker et al. stated that lichen planus affected the middleaged adults, which was consistent with this study ${ }^{7}$.

This study revealed that male $16(36.4 \%)$ and female $28(63.6 \%$ ) were affected which was similar to the report made by Katta that the prevalence of lichen planus was slightly higher in women ${ }^{1}$. In this study considering the site of lesion, skin 44(100\%) involved but mucous membrane $19(43.2 \%)$, nail $10(22.7 \%)$ and hair follicle $3(6.8 \%)$ involved. Although, these findings were not consistent with Daoud and Pittlekow (2008) who reported that mucous membrane involvement occured in approximately 60 to $70 \%$ of patients with lichen planus ${ }^{2}$. Smaller sample size did not give conclusive epidemiological result. In the present study it might be happened that smaller sample size was the cause of this dissimilarity.

The mean duration of disease was 18.7( \pm 4.0$)$ months for group-A and 17.5( \pm 5.6$)$ months for group-B. But the mean difference was not statistically significant ( $\mathrm{p}>0.05)$.

In this study clinical examination and laboratory investigations to evaluate the major adverse effects showed that in group-A, none developed anaemia and edema in subsequent follow up but 3(14.2\%) patients in group-B developed anemia and $12(57.1 \%)$ patients in group-B develoed edema. Body weight increased in group-A from 55.9 $( \pm 2.4)$ to $56.5( \pm 2.4) \mathrm{Kg}$ and group-B from $58.7( \pm 2.6)$ to $61.5( \pm 2.5) \mathrm{Kg}$. Mean difference of body weight was found between group-A and group-B $(\mathrm{p}<0.05)$ indicating mean body weight increased in group-B compared to group-A. Al-Mutairi $\mathrm{N}$ et al. stated that edema and weight gain was the major adverse effect of betamethasone9. This study also showed the similar scenario.

Adverse clinical symptoms like diarrhea, nausea, headache, alopecia and fatigue developed in both groups of patients during follow up period. The percentage of complications were found to be higher among group-B compared to group-A, but the difference was not statistically significant ( $\mathrm{p}>0.05)$. Dyspepsia developed in group-A $11(47.8 \%)$, but in group-B $15(71.4 \%)$. Statistically significant difference was found between two groups of patients $(\mathrm{p}<0.05)$. Hye $\mathrm{MA}^{2}$ showed that betamethasone caused dyspepsia in $62 \%$ of patients.

Among group-A, none complained of acne, mooning face and striae from baseline to follow up period. But among group-B, acne 10(47.6\%), mooning face $8(38.1 \%)$ and striae $8(38.1 \%)$ developed during the follow up period. Statistically significant difference was found between two 
groups of patients $(\mathrm{p}<0.05)$. Hye $\mathrm{MA}^{2}$ and $\mathrm{Al}-$ Mutairi N et al. ${ }^{9}$ showed acne developed $35.5 \%$ \& $42.9 \%$ \& mooning face developed $49.2 \%$ \& $37.5 \%$ which corresponded more or less with this study.

Among group-A, none developed purpura and hypertrichosis from baseline to follow up period, but among group-B, purpura 2(9.5\%) and hypertrichosis $4(19.0 \%)$ developed during follow up period. On the contrary, mouth ulcer had been developed in both groups of patients during follow up. However, no statistically significant difference was found between two groups of patients $(\mathrm{p}>0.05)$.

Among the female patients, initially none complained menstrual abnormality in both groups of patients but during follow up period, menstrual abnormality such as amenorrhoea, oligomenorrhoea, polymenorrhoea developed $5(71.54 \%)$ in group-B, but none developed menstrual abnormality among group-A. Jang N \& Fischer $\mathrm{G}^{\mathbf{1 4}}$ described that methotrexate did not cause menstrual abnormality. These two findings were almost consistent with each other.

Haematological parameters of WBC counting and ESR measurement during follow up period showed that no statically significant mean difference was observed between group-A and group-B ( $\mathrm{p}>0.05$ ). A decreasing trend of blood hemoglobin level was observed. But no statistically significant mean difference was found between two levels such as baseline to $1^{\text {st }}$ week of observation, or $1^{\text {st }}$ week to $2^{\text {nd }}$ week observation and so on $(p>0.05)$. Similarly no statistically significant mean difference was found between group-A and group-B in each level of observation such as at baseline, $1^{\text {st }}$ week, $2^{\text {nd }}$ week \& so on $(\mathrm{p}>0.05)$ (Fig.1). Among group-A, the platelet count decreased from baseline to $1^{\text {st }}$ follow up and then gradually increased up to $6^{\text {th }}$ week, followed by decreased the count. In group-B, a decreasing trend of platelet counts was observed up to $2^{\text {nd }}$ week and then increased at $6^{\text {th }}$ week, but subsequently it decreased. Analysis indicated that no statistically significant mean difference of decreased number of platelet count in different stages within group-A and group-B $(\mathrm{p}>0.05)$ were observed (Fig. 2). Carolyn AB \& Melissa $\mathrm{IC}^{5}$ described that methotrexate reduced WBC count, $\mathrm{Hb} \%$ and platelet count but these were inconsistent with our study. Difference in the study results might be due to short duration of study and small sample size.

Biochemical parameters showed that an increasing trend of SGPT was observed among group-A. However, no statistically significant mean difference was found within the group from baseline to $1^{\text {st }}$ follow up, $1^{\text {st }}$ follow up to $2^{\text {nd }}$ follow up and so on. Similarly, no statistically significant mean difference was found between group-A and group-B in different follow up $(\mathrm{p}>0.05)$. Carolyn $\mathrm{AB}$, Melissa $\mathrm{IC}^{\mathbf{5}}$ and Nylander LE et al. ${ }^{6}$ described that methotrexate increased SGPT level in $15 \%$ of patients but these were inconsistent with our study. Difference in the study results might be due to short duration of study and small sample size.

No statistically significant mean difference of random plasma glucose was found within and between group-A and group-B in different level of observation ( $\mathrm{p}>0.05)$.

Conclusion: The clinical and laboratory parameters were measured to evaluate the major side effects in each follow-up of both groups of patients. The overall adverse effects were less in group-A, who were treated with methotrexate than group-B who were treated with betamethasone. So, methotrexate can be used as an alternative safe drug therapy for the treatment of lichen planus.

\section{References}

1. Katta R. 'Lichen planus'. American Family Physician 2000; 61: 3319-3324.

2. Hye MA. 'Lichen planus and its management: An overview'. Bangladesh Journal of Dermatology, Venereology and Leprology 2006; 23(1): 12-18.

3. Daoud MS, Pittlekow MR. 'Lichen planus', In: Wolff K, Goldsmith LA, Katz SI, Gilchrest BA, Paller AS and Leffell DJ. Fitzpatricks Drematology in general Medicine. $7^{\text {th }}$ ed New York: MacGraw Hill medical publishing division 2008; 244-254.

4. Breathnach SM, Black MM. 'Lichen planus and Lichenoid disorders' In: Burns T, Cox N and Griffiths C. Rook's Textbook of Dermatology. $7^{\text {th }}$ ed. USA: Blackwell Publishing Company 2006; 3: 42.1-42.22.

5. Carolyn AB, Melissa IC. 'Methotrexate in dermatology'. Dermatologic Therapy 2007; 20: 216228 .

6. Nylander LE, Wahlin YB \& Hofer PA. 'Methotrexate supplemented with steroid ointments for the treatment of severe erosive lichen ruber'. Acta Derm Venerol 2001; 82: 63-64.

7. Kachhawa D, Kachhawa V, Kalla G \& Gupta L. 'A clinico-aetiological profile of 375 cases of lichen planus'. Indian Journal of Dermatology, Venereology and Leprology 1995; 61(5): 276-279.

8. Khondker L, Wahab MA \& Khan SI. 'Profile of lichen planus in Bangladesh'. Mymensingh Medical Journal 2010; 19(2): 400-403.

9. Al-Mutairi N, Joshi A, Zaki A, Sharma AK \& NourEldin O. 'Acute generalized lichen planus treated with weekly betamethasone 5-mg oral mini-pulse therapy'. Journal of Drugs in Dermatology 2005; 4(2): 218-220. 
10. Buyuk AY \& Kavala M. 'Oral metronidazole treatment of lichen planus'. Journal of the American Academy of Dermatology 2000; 43(2): 260-262.

11. Chuang TY, Stitle L, Brashear R \& Lewis C. 'Hepatitis $\mathrm{C}$ virus and lichen planus: A case-control study of 340 patients'. Journal of the American Academy of Dermatology 1999; 41(5): 787-789.

12. Hye MA. 'Pathogenesis of lichenoid tissue reactions: An immunological perspective'. Bangladesh Journal of Dermatology, Venereology and Leprology 2003; 20(1): 24-30.

13. Islam MS, Islam AZMM, Islam AKMS \& Wadud MA. 'Association of hepatitis C virus with lichen planus'. Bangladesh Journal of Dermatology, Venereology and Leprology 2005; 22(2): 41-47.

14. Jang $\mathrm{N} \&$ Fischer $\mathrm{G}$. 'Treatment of erosive vulvovaginal lichen planus with Methotrexate'. Australasian Journal of Dermatology 2008; 49: 216219.

15. Johann EG \& James TE. 'Psoriasis', Fitzpatrick's dermatology in general medicine $7^{\text {th }}$ edi. McGraw-Hill Publisher, Sanfransisco, USA 2008; 169-193.

16. Lener EV, Brieva J, Schachter M, West LE, West DP \& Azhary RA. 'Successful treatment of erosive lichen planus with topical tacrolimus', Archives of Dermatology 2001; 137: 419-422.

17. Mobini N, Toussaint S \& Kamino H. 'Noninfectious erythematous, papular, and squamous diseases', in: Elder D, Elenitsas R and Johnson (jr), BL (editors). Lever's Histopathology of the skin, $9^{\text {th }}$ edition New York: Lippincott, Willims and Wilkins publishers, Philadelphia 2005; 179-214.

18. Passeron T, Lacour JP, Fontas E \& Ortonne JP. 'Treatment of oral erosive lichen planus with $1 \%$ pimecrolimus cream', Archives of Dermatology 2007; 143: 472-476.

19. Sultana R \& Sayeed MA. 'Role of different factors influencing skin and venereal diseases', Bangladesh Medical Journal (Khulna) 2002; 35(2): 52-55.

20. Torti DC, Jorizzo JL \& McCarty MA. 'Oral lichen planus: A case series with emphasis on therapy'.Archives of Dermatology 2007; 143: 511-515.

21. Turan H, Baskan EB, Tunali S, Yazici S \& Saricaoglu H. 'Methotrexate for the treatment of generalized lichen planus'. Journal of the American Academy of Dermatology 2009; 60(1): 164-166.

22. Warren RB \& Griffiths CEM. 'The potential of pharmacogenetics in optimizing the use of methotrexate for psoriasis'. British Journal of Dermatology 2005; 153: 869-873.

23. Wolverton SE. 'Systemic corticosteroids'. Comprehensive Dermatologic Drug Therapy. $3^{\text {rd }}$ edition: W. B. Saunders company publisher, Philadelphia 2001; 109-146.

24. Zakrzewska JM, Chan ESY \& Thornhill MH. 'A systematic review of placebo-controlled randomized clinical trials of treatments used in oral lichen planus'. British Journal of De rmatology 2005; 153: 336-341.

25. Cribier B, Frances C and Chosidow, O. 'Treatment of lichen planus: An evidence-based medicine analysis of efficacy', Archives of Dermatology 1998; 134: 15211530.

26. Waller DG, Renwick AG and Hiller K."Corticosteroids (glucocorticoids and mineralocorticosteroids)', In: Medical Pharmacology and Therapeutics. BW Saunders, Edinburgh 2001. 